\title{
Empirical Analysis on Relationship between Money Supply and Economic Growth in China
}

\author{
Abuduaini Awuti \\ Human Resource Research Institute \\ Urumqi Vocational University \\ Urumqi, China 830002
}

\begin{abstract}
The relationship between money supply and economic growth is the focus of attention all the time. In recent years, with the rapid development of Chinese economy, the money supply of RMB increases in successive years. It is of great necessary to conduct empirical analysis on the relationship between money supply and GDP of our country to ensure a balance, healthy and rapid economic development. By selecting the data from 1986 to 2013, 27 years in total, it conducts empirical analysis on this issue through unit root test, Granger causality test, co-integration test and establishment of error correction model, then it comes to a conclusion.
\end{abstract}

Keywords-money supply; M2; GDP

\section{INTRODUCTION}

How does money supply influence economic growth is the first problem faced to research the monetary policy theory of central bank. The reasons are as follows: firstly, the operation and running of the whole monetary policy of central bank revolve around money supply; secondly, macroeconomic regulation and control by central bank is to study whether it can influence the specific economic variables of employment, output, price of commodities, international balance of payment, etc. by means as forecasted through control and regulate the money supply, further to regulate macro economy and realize the objectives predicted of regulation and control; thirdly, judge the quantity of money, intensity of cash flow and level of commodity price, etc. a series of problems.

As the main operating mean of Chinese money policy, the regulation and control of money supply is a double-edged sword for the development of domestic economy. And how to properly control and regulate the money supply becomes the problem demanding prompt solution in current China. Proper money supply is an effective promoter for the stable and rapid development of economy, which can promotes the stable development of our country in high speed; however, whether the short-term facilitation can remain a sustainable economic growth for a long term requires further consideration and discussion. Therefore, thoroughly researching the effectiveness of money supply to the regulation and control of Chinese economy from the perspective of fluctuation of money supply has far-reaching strategic significance for the establishment of domestic money policy and sustainable development of economy.

\section{LITERATURE REVIEW}

Recently, domestic scholars have made a lot of research results of money supply on economic growth. Using the annual time series data of gross domestic product (GDP) and nominal money supply (M2) from 1978 to 2010, Zhong Fanggen (2013) analyzed the relationship between money supply and economic growth in China by means of cointegration test, Granger test and error correction model, and found that there was a long-term equilibrium between money supply and economic growth. Zeng Fanhui (2013) used the monthly data from January 2001 to October 2012 and the vector error correction model (VEC) to empirically analyze the money supply, economic growth and inflation in China. The results show that there was a long-term stable relationship between money supply, inflation and economic growth. In the short term, high economic growth and monetary expansion will bring inflationary pressure, and a certain degree of inflation is conducive to China's economic growth. When high inflation occurs, the government should adopt the austerity monetary policy to relieve the inflationary pressure. By analyzing the gross domestic product and the quarterly data of the money supply of our country from 1999 to 2011, they discussed the relationship between the economic growth and the money supply in China since the reform and opening-up. Using the relevant time-series data from1985 to 2010, Leng Yanli and Peng Zhiyuan (2012) empirically analyzed the relationship between economic growth and money supply, and found that there was a long-term stable equilibrium relationship between economic growth and money supply. Using the annual time-series data of money supply (M1) and the gross domestic product (GDP) from 1978 to 2010 and vector error correction (VEC) model, Huang Gang and Cheng Xiaojun (2012) made an empirical analysis and found that the increase of the money supply has an immediate effect on economic growth in the short term. However, in the long term, with the increase of the money supply, a series of problems, such as inflation, rising prices and devaluation of the RMB will inevitably arise, which will hinder the long-term and stable development of the economy. Shao Tengwei and Ran Guanghe (2011) used vector error correction model and Wald coefficient constraint test to analyze the co-integration relationship between fiscal revenue and expenditure, money supply and economic growth from 1978 to 2009 in China. They concluded that financial revenue and expenditure and 
money supply in the short term are the Granger Causes of economic growth, and the internal fiscal revenue and expenditure and economic growth are the Granger Causes of the increase of the money supply; but in the long run, the relationship between financial revenue and expenditure, money supply and economic growth is not significant. Using the data of money supply and gross domestic product from 1985 to 2009, Zhang Lili and Peng Guofu analyzed the relationship between the money supply (M2) and the economic growth, and found that economic growth is the Grainger Cause of money supply, but money supply is not the Grainger Cause of economic growth and there is a long-term stable equilibrium relationship between the actual money supply and the economic growth. Zhang Yongsheng, Yang Weikun, Sang Yibo and Zhou Huili (2008) studied the relationship between Chinese money supply, economic growth and price level by means of the relevant time-series data and Tobin model, and concluded that there is a positive correlation between the money supply and the economic growth, and the increase of the money supply will promote the economic growth of our country.

In general, many researchers believe that there is a longterm stable equilibrium relationship between money supply and economic growth. The increase of money supply leads to economic growth, and there is a positive correlation between them. Money supply is the Grainger causality of economic growth. The studies of some researchers have also shown that the relationship between money supply and economic growth is significant in the short term, and not significant in the long term. Other researchers believe that the money supply is not the Grainger causality of economic growth, but economic growth is the Granger causality of money supply. In other words, the increase of money supply will not cause economic growth, but economic growth causes the increase of money supply. In comparison, most scholars have come to the previous point of view. There are two contradictory conclusions about the same problem, which may be the reason of constructing the different index systems. After all, financial development is a macroscopic concept, which contains a wide range of contents. Financial development can be seen as a synthesis of the specific projects development which are contained therein, and the development of specific projects is not entirely synchronous. Therefore, when constructing the index system of financial development, it is unavoidable to produce different results because of the difference of selecting Index. Based on the annual data of real money supply and actual gross domestic product from 1986 to 2013, this paper empirically studies the relationship between Chinese money supply and economic growth by means of unit root test, cointegration test, Granger causality test, error correction model (EMC) and other quantitative analysis methods.

\section{DATA DESCRIPTION AND INDEX SELECTION}

\section{A. Data Description}

By observing the curve that indicates the change of GDP and money supply from 1986 to 2013 , we can see that the variation trends of M2, M1 and M0 are basically consistent with GDP and the rate of change of M2 is evidently larger than the rate of change of GDP. However, in some years, there exist some reverse situations, and it is more obvious that the change direction of GDP is opposite to that of M2 in the late 90s. In the late 80s, the gap between GDP and M2 is not big, and even GDP is slightly higher than M2. However, in the 90s, the growth of M2 begins to accelerate and gradually exceeds GDP with the deepening of reform and opening up.

\section{1) Trend analysis}

The sample range of data adopts the annual data from 1986 to 2013. From the results of "Fig. 1", we can see that the absolute value of money of gross domestic product (GDP), quasi-money (M2), money (M1) and money in circulation (M0) from 1986 to 2013 in China is almost in the same direction, and these four indicators have an upward trend of development in the time interval, which reveals that there is a certain correlation between the four indicators. After 1995, in other words, the People's Bank of China issued the notice People's Bank of China Provisional Measures for the Statistics and Publication of Money Supply. The stock of M2 is higher than GDP and the gap increases with time. 

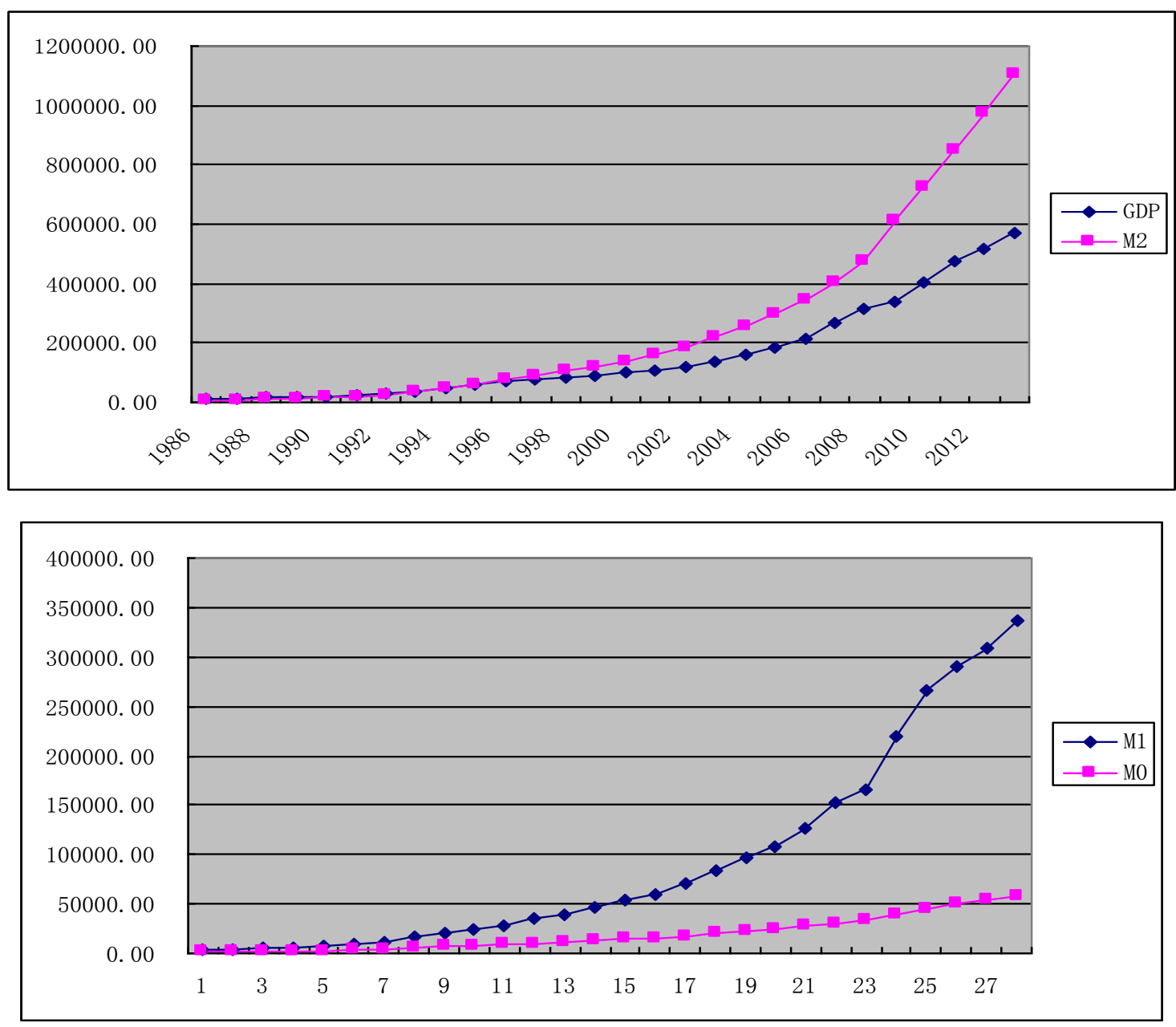

Fig. 1. The trend graph of China's GDP, M2, M1 and M0 from 1986 to 2013.

We can observe the relationship between monetary growth rate and the growth of GDP from the "Fig. 2". When money supply is increased, the growth rate of GDP also increases. When money supply is reduced, the growth rate of GDP also slows. Because of the inertia of economic growth and the hysteresis quality of policy, there are some inconsistencies in some years occasionally, and then they are presented as the same trend. The trend of M2 growth rate is best fitting with GDP growth rate.

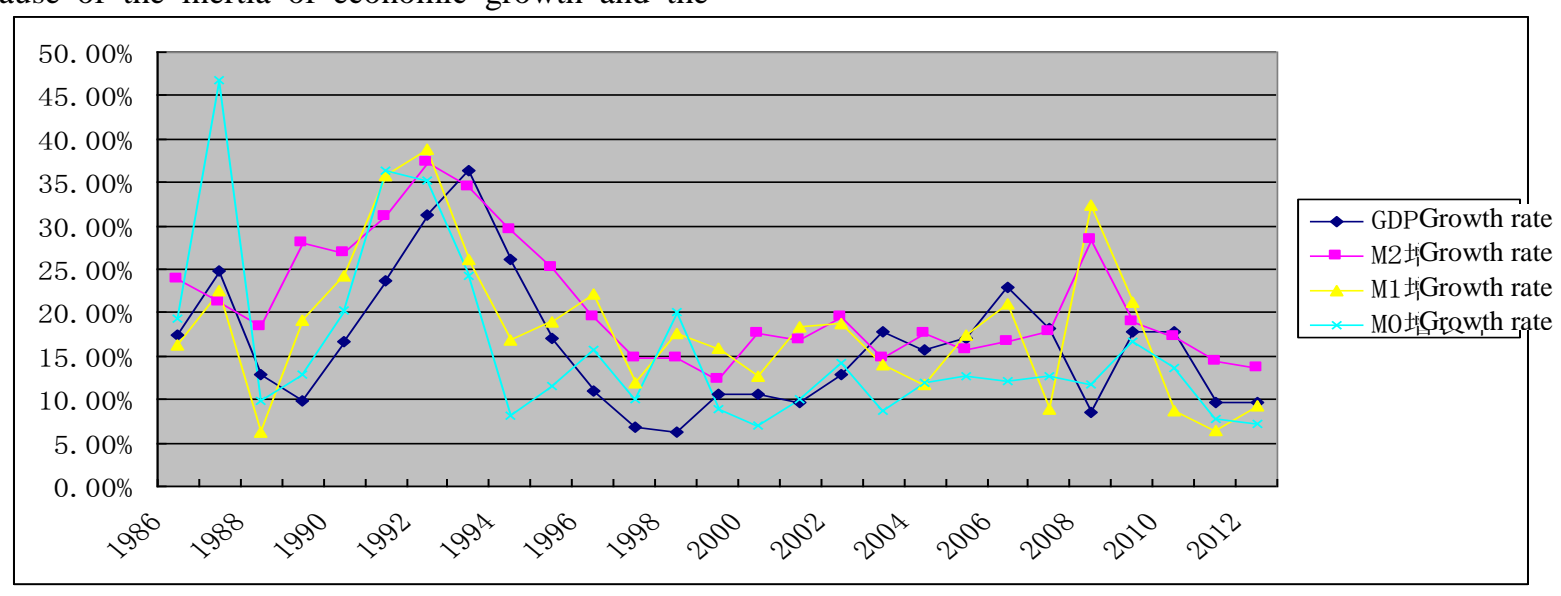

Fig. 2. Diagram of the relationship between growth rates. 


\section{2) Correlation analysis}

Correlation analysis is to judge the close degree between the two variables and whether there is a linear relation through the magnitude of correlation coefficient between the two variables. The number of correlation coefficient is between -1 and 1 . It is a positive correlation when the number is greater than zero, a negative correlation when the number is less than zero and no correlation when the number is equal to zero. There is no linear relation when the number is equal to zero. The absolute value of correlation coefficient is generally divided into four levels: the number below 0.3 is regarded as no correlation; the number between 0.3 and 0.5 is low correlation; the number between 0.5 and 0.8 is significant correlation; the number above 0.8 is high correlation. By comparing the correlation coefficients of GDP, M2, M1 and M0 and the correlation coefficients of GDP growth rate, M2 growth rate, M1 growth rate and M0 growth rate, we can analyze three levels of money supply and economic close degree. The coefficient table is as the follows

The results of "Table I" indicate that the correlation coefficients of M0, M1, and M2 with GDP are 0.99603, 0.996785 , and 0.994947 respectively. The correlation between three levels of money supply and GDP is highly related, and the correlation between M0 and economic growth is the smallest, and the correlation between M1 and economic growth is the highest.

The results of "Table II" show that the correlation coefficients of M2 growth rate, M1 growth rate, and M0 growth rate with GDP growth rate are 0.652264, 0.473504, and 0576188 respectively. The correlation of M1 and economic growth is the weakest and the correlation of M2 and economic growth is the strongest.

TABLE I. The CORRELATION COEFFICIENT Figure of GDP, M2, M1 AND M0

\begin{tabular}{|l|l|l|l|l|}
\hline & \multicolumn{1}{|c|}{ GDP } & \multicolumn{1}{c|}{ M2 } & \multicolumn{1}{c|}{ M1 } & \multicolumn{1}{c|}{ MO } \\
\hline GDP & 1 & 0.996039 & 0.996785 & 0.994947 \\
\hline M2 & 0.996039 & 1 & 0.995665 & 0.986993 \\
\hline M1 & 0.996785 & 0.995665 & 1 & 0.993267 \\
\hline MO & 0.994947 & 0.986993 & 0.993267 & 1 \\
\hline
\end{tabular}

TABLE II. THE CORRELATION COEFFICIENT FIGURE OF GDP GROWTH RATE, M2 GRowTH RATE, M1 GRowTh RATE AND M0 GROWTH RATE

\begin{tabular}{|l|l|l|l|l|}
\hline & $\begin{array}{c}\text { GDP } \\
\text { growth } \\
\text { rate }\end{array}$ & $\begin{array}{c}\text { M2 growth } \\
\text { rate }\end{array}$ & $\begin{array}{c}\text { M1 } \\
\text { growth } \\
\text { rate }\end{array}$ & $\begin{array}{c}\text { M0 } \\
\text { growth } \\
\text { rate }\end{array}$ \\
\hline $\begin{array}{l}\text { GDP growth } \\
\text { rate }\end{array}$ & 1 & 0.652264 & 0.473504 & 0.576188 \\
\hline M2 growth rate & 0.652264 & 1 & 0.755349 & 0.530524 \\
\hline M1 growth rate & 0.473504 & 0.755349 & 1 & 0.657998 \\
\hline M0 growth rate & 0.576188 & 0.530524 & 0.657998 & 1 \\
\hline
\end{tabular}

\section{B. Index Selection and Variable Description}

The money supply of our country has experienced two significant adjustments since 80s. The first time was in 1992. Before 1992, money supply statistical caliber of our country only included four state-owned commercial banks and rural credit cooperatives. After 1992, it extended to policy banks, other commercial banks and urban credit cooperatives. The second tine was in 1997. After 1997, the People's Bank of China further expanded the scope of statistics of money supply, and the data of department and institution of the real estate credit department, the international business department and the credit card department owned by the commercial banks was also calculated in the money supply. At present, China's published money supply has MZ, M1 and M0. M0 represents the current cash and its scope is too narrow. M1 is narrow money, and it mainly reflects the impact of money supply on economy from the perspective of realistic demand. M2 is broad money, in addition to reflecting the influence of money supply on economy from the perspective of demand, it also reflects the relationship between money supply and the macro economy from the perspective of supply. The definition of money in International Monetary Fund is the international standard statistical method, and most western countries use the board money M2 as the monetary index, and many model analyses also indicate that MZ is an appropriate monetary index, so this paper mainly takes the money supply M2 as the empirical analysis data.

Gross domestic product (GDP) refers to the market value of all the finial products and services produced by an economic society (a country or area) by applying the essential productive factors. Therefore, GDP can be used as a measure of measuring the economic strength and economic development level of a country (or area). State Statistical Bureau only publishes nominal GDP, considering the impact of prices, and it introduces the consumer price index (CPI) to eliminate the impact of prices. We can work out the actual gross domestic product through the formula of RGDP $=$ GDP $\times 100 / C P I$ and obtain the actual money supply through the formula of RM $2=\mathrm{M} 2 \times 100 / \mathrm{CPI}$. To eliminate the influence of dimension and heteroscedasticity phenomenon existing in time series, we both take the natural logarithm of the two indexes.

In the selection of sample range of data, we choose the annual data from 1986 to 2013 as the samples of empirical research. Before 1985, the economic openness development degree of our country was very low, and the planned economy occupied the main body and it contained many institutional, structural and policy factors, which was not conducive to our analysis of the impact of money supply on the macro economy, so we choose the data after 1985 . In this paper, the actual gross domestic product is applied to represent economic growth and the index of money supply $\mathrm{MZ}$ published by People's Bank of China is used to represent money supply. The data mainly come from China Statistical Yearbook over the years and the data provided by People's Bank of China Network. In the aspect of data processing, money supply is M2 and the price level chooses fixed base consumer price index (the number was 100 in last year). All the data are computed by using Eviews6.O. 


\section{EMPIRICAL ANALYSIS}

\section{A. Unit Root Test of Variables}

The stationarity of the selected variables in the time series model is the most basic factor of modern econometric. Only the economic variables in the model to meet the requirements of stationarity, can our econometrics analysis be regarded as effective. However, most of the time series data we are adopting are non-stationary and some problems such as false correlation and spurious regression are prone to happen, which can affect our conclusions. To avoid these problems, in the process of empirical analysis of time series, we adopt unit root test to examine our selected time series variables. This paper uses the method of Augmented Dickey-Fuller test(ADF) to examine some data. In the process of unit root test, there are three forms of time series generative process. The first form is without constant term and time trend, and the second form only contains constant term but no time trend, and the third form contains both constant term and time trend. This paper uses the last form.

$$
\Delta \mathrm{y}_{\mathrm{t}}=\mu+\beta \mathrm{t}+\delta \mathrm{y}_{\mathrm{t}-1}+\sum_{\mathrm{j}=1}^{\mathrm{p}} \Delta \lambda_{\mathrm{j}} \mathrm{y}_{\mathrm{t}-\mathrm{j}}+\mathrm{u}_{\mathrm{t}}
$$

By using Eviews6.0 software, the unit root tests of each variable level value and the first order difference value are carried out respectively. The test results are shown in "Table III".

From the calculation results, we can see that when the first-order lag of level value LNRGDP is in regression, and the ADF statistic is -1.348471 , while the $1 \%$ critical value is 3.737853 , and the $5 \%$ critical value is -2.991878 , and the $10 \%$ critical value is -2.635542 , and the $\mathrm{P}$ value is $59.13 \%$, which is far greater than $10 \%$. Accepting original hypothesis shows that LNRGDP cannot be passed by unit root test, that is, it cannot reject the unit root, and LNRGDP is a non-stationary time series. When the first-order lag of level value LNRGM2 is in regression, and the ADF statistic is -0.809015 , while the $1 \%$ critical value is -4.339330 , and the $5 \%$ critical value is 3.587527 , and the $10 \%$ critical value is -3.229230 , and the $\mathrm{P}$ value is $95.22 \%$, which is far greater than $10 \%$. Accepting original hypothesis shows that LNRM2 cannot be passed by unit root test, that is, it cannot reject the unit root, and LNRM2 is a non-stationary time series. But when the firstorder lag of first order difference D (LNRGDP(-1)) of LNRGDP is in regression, and the ADF statistic is -3.642540, while the $1 \%$ critical value is -4.467895 , and the $5 \%$ critical value is -3.644963 , and the $10 \%$ critical value is -3.261452 , and the $\mathrm{P}$ value is $5.02 \%$, which is less than $6 \%$. Rejecting original hypothesis shows the conclusion of accepting nonexistent unit root. But when the first-order lag of first order difference D (LNRM2 (-1)) of LNRM2 is in regression, and the ADF statistic is -3.835129 , while the $1 \%$ critical value is -4.356068 , and the $5 \%$ critical value is -3.595026 , and the $10 \%$ critical value is -3.233456 , and the $\mathrm{P}$ value is $3.07 \%$, which is less than $6 \%$. Rejecting original hypothesis shows the conclusion of accepting nonexistent unit root. According to the above unit root test, it can show that both sequence LNRGDP and LNRM2 are non-stationary sequence sets and integrated of order sequences. The sequence D (LNRGDP (-1)) and D (LNRM2 (-1)) are stationary sequences.

TABLE III. Unit RoOt TEST RESUlts OF VARIABLES

\begin{tabular}{|l|l|l|l|l|l|l|}
\hline \multicolumn{1}{|c|}{ Variable } & $\begin{array}{c}\text { Test form } \\
(\mathbf{C , T , N})\end{array}$ & ADF value & $\begin{array}{c}\text { Critical } \\
\text { value } \\
\mathbf{( 1 \% )}\end{array}$ & $\begin{array}{c}\text { Critical } \\
\text { value } \\
\mathbf{( 5 \% )}\end{array}$ & $\begin{array}{c}\text { Critical } \\
\text { value } \\
(\mathbf{1 0 \%})\end{array}$ & P value \\
\hline LNRGDP (-1) & $(\mathrm{C}, \mathrm{T}, 1)$ & -.348471 & -3.737853 & -2.991878 & -2.635542 & 0.5913 \\
\hline D(LNRGDP $(-1)$ & $(\mathrm{C}, \mathrm{T}, 5)$ & -.642540 & -4.467895 & -3.644963 & -3.261452 & 0.0502 \\
\hline LNRM2 (-1) & $(\mathrm{C}, \mathrm{T}, 1)$ & -.809015 & -4.339330 & -3.587527 & -3.229230 & 0.9522 \\
\hline D(LNRM2 (-1) & $(\mathrm{C}, \mathrm{T}, 0)$ & -.835129 & -4.356068 & -3.595026 & -3.233456 & 0.0307 \\
\hline
\end{tabular}

${ }^{\text {a. }}$ Note: $(\mathrm{C}, \mathrm{T}, \mathrm{N})$ represents constant term and time trend; Lag order is N; D represents difference operator; The selection of time-delay terms order is based on the AIC criterion

\section{B. Co-integration Test}

Co-integration analysis theory is a powerful tool to deal with long-term equilibrium relationship and short-term fluctuation of non-stationary economic time series in recent years. The basic idea is that if the two or more than two time series variables are non-stationary, but a linear combination of them is stationary, and there is a long-term stable equilibrium relationship existing in those variables (co-integration relationship). The economic significance of co-integration analysis is that for two or more than two variables with their respective long-term fluctuation rules, and if they are cointegrated, and there is a long-term equilibrium relationship between them. On the country, if the two or more than two variables are not co-integrated, there is no long-term equilibrium relationship between them. Error Correction Model (ECM) is based on the theory of co-integration, which can reflect the deviation degree of system to equilibrium state in a short-term, in other words, the long-term equilibrium error is used as the correction of short-term fluctuation, and the adjustment information about the deviation degree can be obtained.

At present, the main methods of co-integration test are the two steps method of Engle and Granger (1987) and maximum likelihood principle of Johansen and Juselius (1990, 1992). Gonzalo (1994) obtained the results by using simulation analysis, which showed that the test of Johansen is more steady and better than the two steps method of Engle and Granger (1987).

The two steps method of Engle and Granger (1987) is based on the co-integration test between the two variables, and the basic idea is that: First, an ordinary OLS linear regression should be carried out to these variables which are needed to test to obtain the residual sequence. Then, the residual should be carried out a unit root test. If the residual sequence dose not have a unit root, there is a co-integration relationship between variables. 
According to the above results, it can be concluded that the sequence, LNRGDP and LNRM2 belong to the sequence of integrated of first order, therefore, in order to inspect whether they are interrelated in the long-term, co-integration test can be carried out. The test results are as follows: LNRM2

LNRGDP builds the following regression model for

$$
L N R G D P=\beta_{1}+\beta_{2} L N R M 2+\mathrm{u}_{\mathrm{t}}
$$

$\mathrm{t}=1,2, \quad \cdots \cdots, \quad 28 \quad(2)$

The OLS estimation of regression to the equation (4) is:

$$
L N R G D P=2.269034+0.785768 \mathrm{LN} R M 2
$$

$$
\mathrm{t} \quad=(27.23437) \quad(109.7531)
$$

$$
\mathrm{R} 2=0.9978 \quad \mathrm{~F}=12045.75 \mathrm{P}=0.0000 \mathrm{DW}=0.458591
$$

The upper residual should be carried out a unit root test, and the results of unit root test of residual are shown in "Table IV".

TABLE IV. The Results of Unit Root Test of REsidual ET

\begin{tabular}{|l|l|c|c|c|c|}
\hline $\begin{array}{c}\text { Test form } \\
(\mathbf{C}, \mathbf{T}, \mathbf{N})\end{array}$ & ADF value & $\begin{array}{c}\text { Critical } \\
\text { value } \\
(\mathbf{1 \%})\end{array}$ & $\begin{array}{c}\text { Critical } \\
\text { value } \\
(\mathbf{5 \%})\end{array}$ & $\begin{array}{c}\text { Critical } \\
\text { value } \\
(\mathbf{1 0 \%}\end{array}$ & P value \\
\hline$(\mathrm{C}, 0,1)$ & -3.923484 & -2.656915 & -1.954414 & -.609329 & 0.0004 \\
\hline$(\mathrm{C}, 0,1)$ & -3.923484 & -2.656915 & -1.954414 & -.609329 & 0.0004 \\
\hline
\end{tabular}

The test results indicate that residual sequence reject the original hypothesis $(0.0004<0.01)$ at significance level of $1 \%$, so the residual term can be determined as a stationary column, that is, the above results show that there is a co-integration relationship between LNRGDP and LNRM from 1986-2013, that is the co-integration vector of $\mathrm{C} 1(1,1)$ is $(1,2.269034$, 0.785768 ).

Through the co-integration test, we can know that there is a long-term stable equilibrium relationship between money supply and economic growth. Unfortunately, co-integration relationship between money supply and economic growth can only reveal that there is a certain stable proportional relation, but it can not make sure whether this relationship is causality or not. Therefore, Grainger causality test will be used to test whether there is a causality between money supply and economic growth.

\section{Grainger Causality Test}

From the perspective of development history of econometrics, the concept of Grainger causality is earlier than VAR model. However, the Grainger causality essentially applies the VAR model to carry out a set of coefficient significance tests. Grainger causality can be used to examine whether the all lag terms of a variable have an impact on the current value of another variable or several variables. If the influences are significant, it illustrates that this variable has a Grainger causality for another variable or several variables. If the influences are not significant, it illustrates that this variable does not have a Grainger causality for another variable or several variables. The original hypothesis of Grainger causality test is that the tested variable is not the causality of dependent variables, if the probability $\mathrm{P}$ value of test is less than the set confidence level, then it is believed that the tested variable constitutes the causality of dependent

\begin{tabular}{|c|c|c|c|c|}
\hline $\begin{array}{c}\text { Lagged } \\
\text { rank }\end{array}$ & $\begin{array}{c}\text { Original } \\
\text { hypothesis }\end{array}$ & $\begin{array}{l}\text { Sample } \\
\text { number }\end{array}$ & $\begin{array}{c}\mathbf{F} \\
\text { statistics }\end{array}$ & P value \\
\hline \multirow[t]{2}{*}{$\begin{array}{l}\text { First- } \\
\text { order lag }\end{array}$} & $\begin{array}{l}\text { LNRM2 is not the } \\
\text { Grainger Cause of } \\
\text { LNRGDP }\end{array}$ & 27 & 0.47142 & 0.4989 \\
\hline & $\begin{array}{l}\text { LNRGDP is not } \\
\text { the Grainger } \\
\text { Cause of LNRM2 }\end{array}$ & 27 & 4.06110 & 0.0552 \\
\hline \multirow[t]{2}{*}{$\begin{array}{l}\text { Second- } \\
\text { order lag }\end{array}$} & $\begin{array}{l}\text { LNRM2 is not the } \\
\text { Grainger Cause of } \\
\text { LNRGDP }\end{array}$ & 26 & 3.65218 & 0.0435 \\
\hline & $\begin{array}{l}\text { LNRGDP is not } \\
\text { the Grainger } \\
\text { Cause of LNRM2 }\end{array}$ & 26 & 3.67306 & 0.0429 \\
\hline \multirow[t]{2}{*}{$\begin{array}{l}\text { Third- } \\
\text { order lag }\end{array}$} & $\begin{array}{l}\text { LNRM2 is not the } \\
\text { Grainger Cause of } \\
\text { LNRGDP }\end{array}$ & 25 & 1.90464 & 0.1650 \\
\hline & $\begin{array}{l}\text { LNRGDP is not } \\
\text { the Grainger } \\
\text { Cause of LNRM2 }\end{array}$ & 25 & 3.68410 & 0.0315 \\
\hline
\end{tabular}
variables, conversely, and it is believed that the tested variable is not the causality of dependent variables. "Table V"

TABLE V. GRAinger CAUSAlity Test Results

According to the above results, we can find that when it is in the first-order lag, the P value that LNRM2 is not the Grainger Cause of LNRGDP is 0.4989, which is greater than the standard value 0.1 . So the test results are not significant, and the conclusion that LNRM2 is the Grainger Cause of LNRGDP change is not established. However, the $\mathrm{P}$ value that LNRGDP is not the Grainger Cause of LNRM2 is 0.0552 , which is less than 0.1 . So the test results are significant, and LNRGDP is the Grainger Cause of LNRM2 change. The method is used to examine the Grainger causality test for second-order lag and third-order lag, and the test results can be found: when it is in the second-order lag, the $\mathrm{P}$ value that LNRM2 is not the Grainger Cause of LNRGDP is 0.0435, which is less than the standard value 0.1 . So the test results are significant, and the conclusion that LNRM2 is the Grainger Cause of LNRGDP change is established. However, the $\mathrm{P}$ value that LNRGDP is not the Grainger Cause of LNRM2 is 0.0429 , which is less than 0.1. So the test results are significant, and LNRGDP is the Grainger Cause of LNRM2 change. When it is in the third-order lag, the $\mathrm{P}$ value that LNRM2 is not the Grainger Cause of LNRGDP is 0.0165 , which is larger than the standard value 0.1 . So the test results are not significant, and the conclusion that LNRM2 is the Grainger Cause of LNRGDP change is not established. However, the $\mathrm{P}$ value that LNRGDP is not the Grainger Cause of LNRM2 is 0.0315, which is less than 0.1. So the test results are significant, and LNRGDP is the Grainger Cause of LNRM2 change. When the lag phase of time increases again, there is no obvious change in the Grainger Cause between the two. 


\section{Establishment of Error Correction Model (ECM) and Parameter Estimation}

The term of "error correction" was first proposed by Sargen (1964), and the formation of basic form of error correction model was proposed by Davidson, Hendry, Srba and Yeo in 1978, so it is also called DHSY model. Tradition economic models usually describe a kind of "long-term equilibrium" relationship between variables, but the actual economic data are formulated by a "non-equilibrium process". Therefore, the dynamic non-equilibrium process of data should be used to approximate the long-term equilibrium process of economic theory. There is a co-integration relationship between LNRGDP and LNRM2 in the above argument, but they themselves do not have stationarity. Therefore, we need to establish the error correction model (ECM). The most common form of error correction model is shown in equation (4)

$$
\Delta \mathrm{y}_{t}=\alpha\left(\mathrm{y}_{\mathrm{t}-1}-\mathrm{k}_{0}-\mathrm{k}_{\mathrm{t}-1}\right)+\beta_{2} \Delta \mathrm{x}_{\mathrm{t}}+\mathrm{u}_{\mathrm{t}}
$$

According to the Grainger causality test results, it is shown that China's money supply is not the Grainger Cause of China's economic growth, but China's economic growth is the Grainger Cause of money supply. In order to investigate the dynamic relationship between, we first establish a longterm equilibrium model of economic time series data LNRGDP and LNRM2 from 1986 to 2013. The equation is :

$$
\mathrm{LNRM} 2=\alpha+\beta L N R G D P+\mathrm{u}_{\mathrm{t}}
$$

The estimation result is

(6)

$$
\mathrm{LNRM} 2=-2.856605+1.269899 L N R G D P+\hat{\mathrm{u}}
$$

$$
\begin{gathered}
\mathrm{T}=\quad(-21.66) \quad(109.75) \\
\mathrm{P}=\quad(0.0000) \quad(0.0000) \\
\mathrm{R}^{2}=0.9978 \quad \mathrm{DW}=0.485877 \quad \mathrm{~F}=12545.75 \quad \mathrm{P}=0.0000
\end{gathered}
$$

Then $\mathrm{ECM}=\hat{\mathrm{u}}$, the error correction term for the last residual sequence, we establish the following error correction model (ECM)

$$
\mathrm{d}(\mathrm{LNRM} 2)=\alpha+\delta \mathrm{E} C M_{\mathrm{t}-1}+\beta \mathrm{d}(L N R G D P)+\varepsilon_{\mathrm{t}}
$$

The estimation result is

$\mathrm{d}\left(\mathrm{LNRM}_{2}\right)=0.048472-0.278249 \mathrm{ECM}_{\mathrm{t}-1}+0.949249 \mathrm{~d}($ LNRGDP $)$ (8)

$$
\begin{array}{llc}
\mathrm{T}=(1.686599) & (-2.178634) & (5.239533) \\
\mathrm{P}=(0.1046) & (0.0394) & (0.0000) \\
\mathrm{R} 2=0.6015440 & \mathrm{DW}=1.577 & \mathrm{~F}=18.11 \quad \mathrm{P}=0.0000
\end{array}
$$

From the results of equation (6), we can see that the coefficient of actual economic growth in long-term equilibrium is 1.239899 , which is greater than 1 . This indicates that the actual economic growth rate is less than the actual growth rate of money supply. Form the results of error correction model of equation (8), we can see that the integrated term reflects the impact of short-term fluctuation of economic trend. The short-term fluctuation of actual money supply can be divided into two parts: one is the impact of short-term actual economic growth fluctuation; the other part is the impact of actual money supply deviating from the longterm equilibrium. The size of error correction term coefficient reflects the adjustment power to deviate from the long-term equilibrium. From the coefficient estimated value -0.2782 , we can see that when the short-term actual money supply is greater than the actual money supply in equilibrium, and it will return to equilibrium with 0.2782 downward adjustment power, on the contrary, it will return to equilibrium with 0.2782 upward adjustment power.

\section{CONCLUSION}

This paper utilizes money supply and economic growth of time series data from 1986 to 2013 to establish an error correction model (ECM) and uses some econometric methods of unit root test, Grainger causality test and co-integration test to do an empirical analysis on the collected and arranged economic data, and the following conclusions can be obtained

1. As a whole, there is a long-term and stable equilibrium relationship between economic growth and money supply of our country. In other words, there is a relatively stable proportional relation between China's economic growth and the change of China's money supply.

2. China's money supply and China's economic growth are not stationarity data, but their first order difference is stationary, that is, the growth rate of economy and the growth rate of money supply are stable.

3. Grainger causality test can indicate that the actual economic growth is the Grainger Cause of the actual money supply, but the actual money supply is not the Grainger Cause of economic growth. This result is the adverse theory of money supply to economic growth, which is adapted to the special period of China's economy. China is now in a transition period from the planned economy to socialist market economy. At the beginning of the reform, China's economy gained rapid development, but the reform of financial system lagged behind the reform of economic system, especially China's interest rate was not marketoriented, and China was still in the stage of financial repression, which contributes to the fact that the conduction path of the growth of money supply promoting economic growth is not smooth, and leads to the fact that the growth rate of China's actual money supply is not the Grainger Cause of actual economic growth rate. Besides, from the theoretical knowledge of the relationship between money supply and social supply and demand, we can know that aggregate supply of social goods decides the money demand for a certain period and the money demand determines the money supply; however, gross domestic product refers to the value of all the final products and services produced by a country or area in a certain period, and economic growth means that the increase 
of products and services provided by society will lead to the increase of money demand, which will lead to the increase of money supply. From this point of view, China's actual economic growth rate is the Grainger Cause of actual money supply growth rate.

4. According to the results of error correction model, we can know that economic growth has increased by one percentage point and the money supply will change by 0.949 percentage point in the same direction, and the size of error correction term can reflect the adjustment power to deviate from the long-term equilibrium. From the coefficient estimated value -0.2782 , we can see that when the short-term actual money supply is greater than the actual money supply in equilibrium, and it will return to equilibrium with 0.2782 downward adjustment power, on the contrary, it will return to equilibrium with 0.2782 upward adjustment power.

\section{REFERENCES}

[1] Leng Yanli, Peng Zhiyuan. The Empirical Study of the Relationship between China's Money Supply and Economic Growth(J), China Collective Economy, 2012, 27th Issue, Page: 65-67.

[2] Shen Weiwei, Lan Tian. The Empirical Study of the Relationship between China's Money Supply and Economic Growth(J), Journal of Yunnan University of Finance and Economics, 23 Volume, 5th Issue, Page: 73-76.

[3] Huang Gang, Zhong Fanggen. An Empirical Study of the Relationship between Money Supply and Economic Growth about China (J), Research of Finance and Education, 2013, 2nd Issue, Page: 36-42.

[4] Gu Weiping. Analysis of Money Supply and Economic Growth (J), COOperative Economy and Science, 2009, 12 Issue, Page: 4-5.

[5] Zhang Xingwang. An Empirical Study of Money Supply and Economic Growth (J), Market Forum. 2009, 7th Issue, Page: 76-77.

[6] Zhang Lili, Peng Guofu. Empirical Study on the Relationship between China's Currency Supply and Economic Growth (J), Economy and Management, 2011, 6th Issue.

[7] Liu Liping. Granger Causality Analysis of Financial Development to Economic Growth in China [J], Economic Research Guide, 2010, 8th, Page: 141-142.

[8] He Jiang, Li Jinhao. Empirical Analysis on the Relationship of Financial Development and Economic Growth (J), Journal of Chongqing University of Science and Technology (social sciences edition), 2010, 5th, Page 88-90.

[9] Lin Yong, Lu Xingneng. Financial Development and Economic Growth: Time-Series Evidence from China (J), Huabei Finance, 2010, 2nd, Page 13-17.

[10] Sun Puyang. Economies Growth and Financial Development in the Large Developing Countries (J), Nankai Journal (Philosophy Literature and Social Science Edition), 2010, 1st, Page: 104-111. 